African Journal of Educational Studies in Mathematics and Sciences Vol. 15, No. 2., 2019

\title{
Primary and junior high school mathematics and science teachers' views on teaching in the Cape Coast Metropolis of Ghana
}

\author{
E. K. Davis, C. Beccles, \& E. C. Intsiful
}

\begin{abstract}
This paper draws on conceptualization of pupil-centred and teacher-centred methods to explore the views of primary school and junior high school (JHS) mathematics and science teachers on teaching. The purpose of the study was to ascertain whether the views of these teachers place the pupils at the centre of the teaching and learning process. The research participants were selected from all the six circuits in the Cape Coast Metropolis using stratified random sampling procedure. Questionnaires were administered and responded to by 157 primary and JHS mathematics and science teachers in the Cape Coast Metropolis of Ghana. The data collected were analysed using both quantitative and qualitative data analysis methods. The findings from the study showed among others that the participants' views about teaching were predominantly teacher-centred. Implications of the findings for mathematics and science teacher education particularly and research in mathematics and science education in Ghana generally are provided.
\end{abstract}

Keywords: $\quad$ science and mathematics teachers; views on teaching; teaching primary science and mathematics; teaching junior high school; science and mathematics

\section{Background to the study}

Mathematics and Science constitute two important subjects which are studied in pre-tertiary curriculum all over the world because of their role in the socioeconomic development of countries. It is therefore not surprising that major international assessment in educational outcomes such as Trends in International Mathematics and Science Studies (TIMSS) and Programme for International Students Assessment (PISA) focus of these subjects. Despite the importance on these subjects, many students in developing countries such as Ghana have difficulty to learn (Mullis, Martin, Foy \& Arora, 2012). This paper contributes to understanding of why Ghanaian students have low achievement in Mathematics and Science, by exploring beliefs/views of teachers about teaching and learning to ascertain whether their views place the students at the centre of the teaching and learning process.

A growing body of literature positions teachers' beliefs as one of the affective variables which influence their practices and decisions they take in the classroom (Dembo 1977; Davis \& Andrzejewski, 2009; Mansour, 2009). Beliefs direct one's thoughts and behaviour (Borg, 2001). Dembo (1977) argues that all teachers have belief or theory about learning that is the very fabric of their teaching strategy. This suggests that teachers' beliefs about learning has the tendency to influence teaching and learning in the classroom. Teachers who see learning mainly as acquisition of knowledge are likely to use teacher-centred methodologies, while teachers who see learning as acquisition of experience are more likely to employ student-centred approaches. It appears evident

\footnotetext{
${ }^{1 \& 2}$ Ernest Kofi Davis and Christopher Beccles are both in the College of Education Studies, University of Cape Coast, Ghana

${ }^{3}$ Etheldreda C. Intsiful is at Komenda College of Education, Komenda, Ghana

Open Access article distributed under the terms of the Creative Commons Attributions License [CC BY-NC-ND 4.0] http://creativecommons.org/licenses/by-nc-nd/4.0. DOI: https://dx.doi.org/10.4314/ajesms.v15i2.2
} 
Primary and junior high school mathematics and science teachers' views on teaching in the Cape Coast Metropolis of Ghana

\section{E. K. Davis, C. Beccles, \& E. C. Intsiful}

from the literature reviewed so far that what teachers may choose to pay attention to in the teaching and learning situation in the classroom depends on what they find important and these are often influenced by their beliefs on teaching and learning.

Beliefs may not always reflect actions or practices (Mansour, 2009; Williams \& Burden, 1997), There could be a mismatch between beliefs and practices due to social and cultural context of schooling (Mansour, 2009). The system of curriculum delivery including assessment (that is, high stake national examinations) and overall national or regional policies on schooling could provide good sources of mismatch between educational beliefs generally and teachers' beliefs particularly (Fang, 1996; Mansour, 2009). The literature suggests that learners are likely to receive confused and confusing messages in classroom situations where wide discrepancies exist between teachers' beliefs about teaching and their actual classroom practices (Williams \& Burden, 1997).

Different researchers have provided different conceptualizations of beliefs. Nespor (1987), for example, positions beliefs as what one thinks and knows but provide affective filter which shapes one's thinking and information processing. Perkkila (2003) conceptualises beliefs as subjective experienced-based implicit knowledge about a subject and its teaching. While Galvis (2012) looks at beliefs as mental constructs of experience often condensed and integrated into schemata. Drawing on the work of Kagan (1992), Mansour (2009) argues that "as a teacher's experience in the classroom grows, this knowledge grows richer and more coherent and thus forms a highly personalised pedagogy or belief system that actually controls the teacher's perception, judgement and behaviour" (p. 27). Based on the above conceptualizations of beliefs, in this paper, we conceptualised beliefs as what one thinks and knows from experience that shapes the way the person views and deals with his/her world. Thus, we conceptualize beliefs as what primary and junior high school mathematics and science teachers think and know about mathematics and science teaching and learning from their experience that shapes the way they view teaching and learning, and carry out teaching in their classrooms.

Teachers' beliefs related to teaching and learning have been categorised differently by different researchers. Calderhead (1996), for example, categorized beliefs related to teaching and learning into two, that is, (1) teachers' view of teaching as a process of knowledge transmission, and (2) teachers' view of teaching as a process of guiding children's learning. This categorization appears to suggest that teachers' belief about teaching could either reflect teacher-centred beliefs or pupilcentred beliefs. However, literature suggests that this may not always be the case (Mansour, 2009).

Meighan and Meighan (1990) argue that teachers may metaphorically conceptualize students as resisters, receptacles, raw materials, clients, partners, individual explorer and democratic explorers. A teacher who conceptualizes students as resisters or receptacles is likely to hold views that will espouse teacher-centred methodologies. This teacher is likely to see the students as empty vessels who do not have anything meaningful to contribute to the teaching and learning processes. A teacher who conceptualises students as democratic explorers is likely to hold views that espouse pupil-centred methods. This teacher is likely to see the students as active participants in the teaching and learning processes. A teacher who conceptualises students as clients is likely to hold shades of both teacher-centred and pupil-centred approaches. Viewing pupils as clients pre-supposes that both parties would have some roles to play to keep the bargain. This teacher is likely to espouse beliefs that position classroom discourse as being co-led by both the teacher and the pupils.

Some studies have looked at teachers' beliefs in mathematics (Ernest, 1988; Perkkila, 2003) and science (Mansour, 2009). These studies have focused on several aspects of teacher belief. Perkkila (2003) for example, drew on Ernest's (1989) distinction of the nature of mathematics, namely the 
instrumentalist view of mathematics, the Platonist view of mathematics and the problem-solving view of mathematics to explore primary school teachers' view of mathematics and mathematics teaching. The study found amongst others that teachers' beliefs about the content of mathematics are strongly related to their teaching practice as compared to their beliefs about mathematics teaching and learning. Mansour (2009), explored the relationship between teachers' belief and practices and provided framework to support the interpretation of the relationship between the two focusing on science teachers. The study revealed that teachers' beliefs are formed based on experience than theory and that beliefs are influence by social and cultural context. Findings from some of these studies also highlight the influence of teachers' beliefs on their teaching practices (Ernest, 1988; Mansour, 2009).

Despite the abundance of studies on belief in the developed world and observation in literature about the strong link between teachers' beliefs and their classroom decisions and method of delivery, not many studies in Ghana have explored the views of mathematics and science teachers on teaching to ascertain how their views reflect students' performance in mathematics and science. It is against this background of paucity of studies on mathematics and science teachers' views about teaching in Ghana that this study was designed to explore mathematics and science teachers' views about teaching.

\section{Conceptual Framework}

Brady's (1985) conceptualization of the continuum of teacher-centred and pupil-centred methods provided the theoretical lens with which teachers' views were investigated. Table 1 presents Brady's conceptualization of teacher-centred and pupil-centred methods. Brady employs nine items to measure teaching methods focusing on three main areas namely, how the teacher views learning, the role of the teacher in the teaching learning processes and the classroom organization.

Table 1: Brady's conceptualization of the continuum of teacher-centred and pupil-centred methods

\begin{tabular}{l|l}
\hline Teacher-centred & Pupil-centred \\
\hline $\begin{array}{l}\text { Views learning as acquisition of knowledge; } \\
\text { intellectual development. }\end{array}$ & $\begin{array}{l}\text { Views learning as acquisition of experience; } \\
\text { affective development. } \\
\text { Teacher's main function is to instruct. } \\
\text { Emphasises teacher as judge, censor. }\end{array}$ \\
$\begin{array}{l}\text { Teacher's main function is to evoke. } \\
\text { Emphasises teacher as facilitator, supporter. }\end{array}$ \\
$\begin{array}{l}\text { Eupils contribute to selection of learning } \\
\text { experiences. }\end{array}$ \\
$\begin{array}{l}\text { Emphasis on tests and grades. } \\
\text { Eoes not encourages pupil-pupil interaction. }\end{array}$ \\
Evaluation is a teacher responsibility. & $\begin{array}{l}\text { Emphasis on less traditional evaluation. } \\
\text { Emphasises teacher control Evaluation }\end{array}$ \\
\hline
\end{tabular}
Source: Brady’s (1985), p.5.

Brady's (1985) categorization of the continuum between teacher-centred and pupil-centred methods relates to teachers' beliefs. For example, Meighan and Meighan's (1990) conceptualization of teacher beliefs about pupils as resisters, receptacles, raw material, clients, partners, individual explorer and democratic explorers is related to the nature of class interaction. The first four beliefs 
Primary and junior high school mathematics and science teachers' views on teaching in the Cape Coast Metropolis of Ghana

\author{
E. K. Davis, C. Beccles, \& E. C. Intsiful
}

reflect teacher-centred world view whereas the last three reflect pupil-centred world view. We would argue that teachers who hold the first four sets of beliefs about pupils (resisters, receptacles, raw material, clients) are likely to exhibit most (if not all) the teacher-centred characteristics proposed by Brady (1985), while teachers who hold the last three sets of beliefs about pupils (partners, individual explorer and democratic explorers) are likely to exhibit most (if not all) the pupil-centred characteristics proposed by Brady (1985).

\title{
Purpose and the Research Question
}

The study sought to explore the views/beliefs of primary school and junior high school (JHS) mathematics and science teachers on teaching. The aim was to ascertain whether their views place the students at the centre of the teaching and learning process. And, hence, the study was guided by the question 'how pupil-centredness are the views/beliefs of primary and junior high school science and mathematics teachers?'

\section{Methods}

The survey design was used for this study. The research participants comprised 157 trained/professional Primary and Junior High School mathematics and science teachers from twenty Primary and Junior High Schools in the Cape Coast Metropolis of Ghana. One hundred and four of the research participants were primary school teachers while the remaining fifty-three were Junior High School teachers. The research participants were selected from all the six circuits in the Cape Coast Metropolis using stratified random sampling procedure. Each of the circuits formed a stratum from which the research participants were selected to reflect the composition of schools in the circuit (that is, Above-Average, Average and Below-Average achieving schools as well as rural and urban schools).

Questionnaire was the main instrument that was used for data collection. As the study sought to explore mathematics and science teachers' beliefs about teaching, the items in the questionnaire were open-ended type (see Appendix A). This was to enable the participants to express their views and at the same time afford the researchers the opportunity to collect the views of as many participants as possible. The questionnaire was developed by the authors and given to some experienced colleagues in the College of Education Studies, University of Cape Coast, to review the items to ascertain whether they elicited valid response. It was also pre-tested with twenty-five Primary and Junior High school mathematics and science teachers from four schools in Komenda Edina Eguafo Abrem (KEEA) District in the Central Region of Ghana. Through the process a few of the items that were not eliciting valid responses because of lack of clarity were revised. The items in the questionnaire were informed by the conceptual framework.

The questionnaire was administered by the authors to the 157 research participants in the Cape Coast Metropolis of Ghana. The research project was explained to the participants and their consent sought before the administration of the instrument. The data collected were analysed qualitatively and presented as narrative description with illustrative examples. Frequency count (percentages) was also used in the analysis of the results of the study (see Appendix B, for an example). For the purpose of analysis, the responses of the teachers were coded T1, T2, T3, T4, .., T157.

\section{Results}

The results of the views of the Primary and Junior High School mathematics and science teachers are presented based on Brady's (1985) conceptualization of the continuum of teacher-centred and pupil-centred methods. However, the two items relating to assessment and evaluation in Brady (1985) framework were merged in this study for the purpose of analysis of the results from the 
study. This therefore brings the total number of items to eight. Teachers' views on each of the items on Brady (1985) framework have been provided using percentages and typical examples of how these were expressed. Results on each of the items in the frame are provided as follows:

\section{Views on learning}

The majority of the teachers $(70.1 \%)$ held teacher-centred view of learning. Some of their teachercentred views included:

a. "It is the process of gaining knowledge about something"(T141)

b. "It is the process of acquiring knowledge through any form of education " (T 16)

c. "It is the process of acquiring knowledge from a knowledgeable person or teacher" (T80)

d. "Learning is a process of imparting knowledge in any form into individuals under an organized setting"(T156)

The results from the study showed that the majority of the teachers' views on learning, positions learning mainly as acquisition of knowledge, as exemplified in the responses of T141 and T16, "It [learning] is the process of gaining knowledge about something" (T141) and "It [Learning] is the process of acquiring knowledge through any form of education" (T 16) (see also Appendix B). Literature suggests that this view of learning is associated with the behaviourist psychology, which underpins teacher-centred methods. Teachers who hold such views on learning are therefore likely to employ teacher-centred methods since teachers' views/beliefs about learning are believed to influence the decisions they take in their classroom (Dembo, 1977; Williams \& Burden, 1997; Davis \& Andrzejewski, 2009).

The teacher's main function in the teaching and learning process:

Participants had varied views on the teacher's main function. These were: to facilitate learning (55\%); to impart knowledge (30); and to instruct (15). Some of the typical response relating to the main function of the teacher included:

a. "leader and facilitator" (T 48)

b. "to facilitate the learning process through instruction and direction giving" (T 37)

c. "to impart knowledge to the children to understand" (T 12)

d. "to instruct the pupils what to do" (T10)

A significant minority (45\%) of the teachers held teacher-centred view about the main function of teachers in the teaching learning process. This is reflected in the response of Teacher 10 (T10) as "...to instruct the pupils what to do." Although more than half of the respondents' views about the main function of teachers as facilitators reflects pupil-centred world view, one is not sure whether some of the respondents understand what it means for a teacher to facilitate learning. This was evident in Teacher 37's (T37) response as "to facilitate the learning process through instruction and direction giving". Process of learning through instruction and direction giving reflects a philosophical perspective that positions the teacher as the one who directs the whole process of teaching and learning, which is the behaviourist psychology. Beliefs associated with behaviourist psychology reflects teacher-centred methods.

The role of the teacher:

The majority $(65 \%)$ of the respondents' views position the teacher as judge or censor. Some of the typical responses from the participants included:

a. "is the teacher who decides what is right or wrong in the lesson because he/she planned, gather (sic) information for all that is to taught and learned" (T 85)

b. "the teacher is the one who decides what is wrong or right in the classroom since he is the one 
Primary and junior high school mathematics and science teachers' views on teaching in the Cape Coast Metropolis of Ghana

\section{E. K. Davis, C. Beccles, \& E. C. Intsiful}

impacting (sic) knowledge" (T 87)

c. "the teacher; because the teacher is the one who has mastered the subject matter." (T 118)

d. "the teacher because he is knowledgeable and has the requisite skill to guide the learner." (T 95).

It is evident from the responses of the participants on the role of the teacher in the teaching and learning process that their views generally reflected teacher-centred view on teaching. Views expressed by Teacher 87 , on who decides what is right and wrong and why? as "the teacher is the one who decides what is wrong or right in the classroom since he is the one impacting (sic) knowledge", for example, suggests that the teacher is the one who owns the knowledge and the students' duty is just to follow the teacher's procedures and make sure the procedures are well internalised and reproduced correctly as and when the teacher wants them to do so.

\section{Selection of learning experience}

The majority $(80 \%)$ of the respondents were of the view that the teacher alone should select learning experiences. Some of their typical responses on who selects the learning experience were:

a. "the teacher, knowing the performance level of his or her pupils can decide what should be taught and how it should be learnt" (T 15)

b. "teacher because the teacher knows the intellectual ability of the children" (T 128)

The results on the selection of learning experiences also shows that the overwhelming majority of the teachers believe that they are solely responsible for the selection of learning experience. The students have no role in the selection of what goes into their studies in school. This world view also reflects behaviourist world view, where the organisation of the learning experience that would maximise the possibility of students coming out with the right response is the sole responsibility of the teacher.

\section{Classroom interaction}

The respondents had varied views about classroom interaction. A little less than a third $(30.1 \%)$ had views that positioned the learner at the centre of classroom interaction, almost a quarter $(24.5 \%)$ had views that positioned the teacher at the centre of classroom interaction, about a fifth $(21.5 \%)$ had views that positioned classroom interaction as being co-led by both teachers and students. A fifth $(25.0 \%)$ gave views that were not clear to the authors. Some of the typical pupilcentred views included:

a. "There should be friendly atmosphere where students can freely express their ideas and teachers come in only when necessary. There should be reinforcement, feedback and a very relaxed atmosphere but orderliness must be in place." (T119)

b. "The instruction should be learner-centred. It be based on activity method where children explore with tools and learning materials to come out with solutions to problems (sic)." (T95)

c. "It should be cordial, free and friendly for pupils to freely express their feelings and ideas" (T90)

Some of the typical teacher-centred views included:

a. "the teacher teaches, the student asks questions and answers teachers questions (sic)." (T17)

b. "A teacher is always seen in front of the pupils where the class is controlled to ensure that teaching and learning process runs smoothly." (T9)

c. "The teacher must brainstorm the students and discuss but the teacher must contribute more as he imparts knowledge." (T70).

Some of the typical views that positioned classroom interaction as being co-led by both the teacher and students included: 
a. "It should be teacher-pupil and pupil to pupil because some pupils understand best when their friends teach them." (T161)

b. "The interaction in the classroom should be two sided such that both the teacher and the learner can acquire some knowledge at the end of the lesson." (T151)

c. "I think the interaction should be more of discussion among pupils and teachers". (T8)

Some of the typical views that were unclear to the authors include:

a. There should be a friendly relationship as well as cordial. (T157)

b. In the classroom, the teacher should interact with the pupils as his own children. (T53)

c. It should be one-on-one. (T29)

Results of teachers views on classroom interaction show that a little more than half $(51.6 \%)$ had views which either placed the child at the centre of the teaching and learning process or positioned classroom interaction as being co-led by both the learner and the teacher. These views show tendency towards dialogic classroom interaction where pupils are given the opportunity to question and discover mathematical fact rather than just following teachers' processes (Groth, 2013). However, Teacher 17's explanation of the classroom discourse as "the teacher teaches, the student asks questions and answers teachers questions (sic)" reflects tendency towards monolithic classroom interaction among teachers who held teacher-centred perspective of teaching. A number of teachers in this category had views that projected vertical classroom interaction as exemplified in the response of Teacher 10 as "Teacher-pupils interaction."

\section{Assessment and Evaluation}

The majority $(85 \%)$ of the participants' responses indicated that they view evaluation as the sole responsibility of the teacher and test and grades as the main tools of assessment. Some of their typical responses on who evaluates the teaching and learning process included:

a. "the teacher because he taught the lesson" (T147)

b. "the teacher because he plans the lesson" (T11)

c. "the teacher because he/she sets the objectives based on the syllabus (T95)

Some of the typical responses relating to tools of assessment included:

a. "through the administration of well organised and proven (valid and reliable) teacher made test" (T150)

b. "by giving them class exercises, class tests and end of term assessments or exam" (T14)

c. "you can determine students' understanding through assessment test" (T15)

The results show that the majority of teachers' views on assessment and evaluation reflected teacher-centred views, since they view assessment as the sole responsibility of the teacher and test as the main tool for assessing students (Brady, 1985). This view does not give room for assessment as learning and assessment for learning, which are associated with student-centred methods and are necessary for development of conceptual knowledge among the students.

\section{Emphasis on group work}

About half $(52 \%)$ of the participants' views revealed that they emphasised group work. The remaining had views which showed they emphasized both group work and individual seat work. Some of the reasons for emphasising group work included:

a. "pupils get to interact with each other and they learn best from each other" (T45)

b. "it encourages cooperation among students" (T146) 
Primary and junior high school mathematics and science teachers' views on teaching in the Cape Coast Metropolis of Ghana

\author{
E. K. Davis, C. Beccles, \& E. C. Intsiful
}

c. "both should be encouraged because using the individual seat helps the student to build confidence and master independence on the other hand when they work in group they master team work" (T156)

The results on teachers' views on group work showed that they generally had pupil-centred view about group work. The response from T146 as "it encourages cooperation among students", for example, supports the belief of students as partners in the teaching learning situation (Meighan \& Meighan, 1990). This belief reflects pupil-centred position on teaching.

\title{
Control of teaching and learning process
}

Overwhelming majority ( $85 \%)$ of the participants' views showed that the teacher controls the teaching and learning process. Some of their typical responses were:

a. "the teacher because he/she is the commander in chief of the classroom" (T78)

b. "the teacher is the boss in the classroom hence he/she should be responsible for controlling the teaching and learning process in the classroom" (T15)

c. "...he/she is supposed to instruct the pupils/students" (T79)

The results on the participants' views on who controls the teaching and learning process in the classroom showed that their views reflected teacher-centred position. The response of T15 as "the teacher is the boss in the classroom hence he/she should be responsible for controlling the teaching and learning process in the classroom" reflects the belief that the student is only a raw material (Meighan \& Meighan, 1990) who has to look up to the teacher and just follow the teacher's processes to obtain the correct results. This view also reflects a monolithic rather than dialogic classroom interaction (Groth, 2013) and supports teacher-centred position on teaching and learning.

\section{Discussion}

As Brady (1985) conceptualization of the continuum between teacher-centred and pupil-centred approaches formed the theoretical lens for this study, the discussion of the study will be informed by same. As already noted in the methodology and results sections, assessment and evaluation in Brady's framework was combined. This made the indicators eight instead of nine in the continuum between teacher-centred and pupil-centred methods.

It was evident from the study that the views of overwhelming majority of teachers on five out of the eight indicators namely, "views on learning", "the role of the teacher", "selection of the learning experience", "assessment and evaluation", and "control of teaching and learning process", reflected teacher-centred position. With the exception of group work in which teachers' views reflected pupil-centred position, their views on the remaining two items were varied with a significant minority of the teachers holding teacher-centred position. A close examination of some of what appeared to be pupil-centred views that positioned the role of the teacher as facilitators such as "to facilitate the learning process through instruction and direction giving" (T37) rather showed element of teacher-centredness.

As we have already highlighted in the literature presented in the background to the study, teachers' beliefs cannot be separated from context of schooling (Mansour, 2009; Kagan, 1992). We therefore argue that views of teachers on the majority of items reflected teacher-centred methods because of the socio-mathematics/science norms that are projected in classroom across the country. The research study in mathematics within the same research locale, for example, showed that teacher-centred methods of teaching, which generally involved teaching of procedures 
followed by application of the procedures by way of working some examples and giving students some class exercise or homework reflected the standard practice projected in the national teaching syllabus and textbooks (Abenyegah \& Davis, 2015; Davis, 2018). This was also reflected in the explanation of classroom interaction of T17, "the teacher teaches, the student asks questions and answers teachers questions (sic)". This sequence of teaching also reflects what is prescribed in lesson plans that are approved by headteachers and circuit supervisors. Once teachers are posted to schools they are immersed into these practices. This sequence of teaching, which dominates the school system, has the tendency to contribute to the teacher-centred perspectives which was exhibited by the research participants. Mansour (2009) argues that "belief control the gaining of knowledge and knowledge influenced beliefs" (p.28). This shows that there is an interaction between belief and knowledge. We argue that unfavourable school conditions such as acute lack of teaching and learning materials for mathematics and science and large class sizes could provide the condition for teachers to adjust into the socio-cultural norms of mathematics and science teaching in schools. Their knowledge of what works in the teaching and learning of mathematics and science in the Ghanaian school context has the tendency to produce the negative views teachers exhibited in the study.

The results from the study also show that teachers' view about teaching may not always reflect either teacher-centred methods or pupil-centred methods. They may reflect method which put both the students and teacher at the centre of the whole teaching learning process. This was evident in the explanation of T151, "the interaction in the classroom should be two sided such that both the teacher and the learner can acquire some knowledge at the end of the lesson."

Results on teachers' views on group work is perplexing since it does not align to their views on "learning", "the role of the teacher", "selection of the learning experience", "assessment and evaluation", and "control of teaching and learning process". For example, a teacher who views his/her role as "... the commander in chief of the classroom" (T78) is likely to promote classroom discourse which is univocal (Groth, 2013). In such a classroom environment group work does not necessarily provide opportunities for students to challenge and discover knowledge by themselves but to master procedures for solving problem through drills by group members. This shows that although the teachers held the teaching belief that positioned students as partners in the teaching learning process (Meighan \& Meighan, 1990), their views on teaching generally supported teacher-centred methods. We would argue that ineffective use of group work could results in the use of teacher-centred methods of teaching. This could explain the misalignment between the findings on views on group work and views on "learning", "the role of the teacher", "selection of the learning experience", "assessment and evaluation", and "control of teaching and learning process".

As a growing body of literature have shown that teachers' views about teaching affect their teaching practices (Ernest, 1988; Mansour, 2009), teachers who hold teacher-centred views on teaching are not likely to provide students with the opportunities that will help them acquire conceptual knowledge. Their teaching methods are likely to promote the acquisition of procedural knowledge (Groth, 2013), which does not produce the kind of understanding that support critical thinking and problem solving, which constitute some of the aims of teaching mathematics and science in Ghana (MoE, 2012a; MoE, 2012b).

\section{Conclusions and implication}

Although teachers' views about teaching cannot always be classified strictly as being teachercentred or pupil-centred, it was evident from the study that the primary and junior high school 
Primary and junior high school mathematics and science teachers' views on teaching in the Cape Coast Metropolis of Ghana

\author{
E. K. Davis, C. Beccles, \& E. C. Intsiful
}

teachers' views on the majority of Brady's (1985) indicators of the continuum between teachercentred and pupil-centred methods showed that their views were predominantly teacher-centred. The sociocultural norms of teaching mathematics and science in Ghana where procedures are taught followed by application of procedures would have to be challenged since teachers' views are influenced by their experience in the social and cultural context of schooling.

Although the rationale of some of the curricula used in preparing teachers for the primary and junior high school levels in Ghana espouse the training of teachers who hold pupil-centred views of learning and projects teachers who employ problem-solving in teaching (see IoE, 2014, for example), the results of this study appear to show that some of the products of these trainings end up holding pupil-centred view of teaching. This calls for the need for the mathematics and science education community in Ghana to look at how the sociocultural context of schooling in the country affect teachers' beliefs about teaching and its possible effect on pupils' performance. There may be the need for dialogue on current sequence of presentation of lessons in mathematics and science which generally involves the teaching of procedures, followed by application of the procedures through class exercise and homework. This sequence of teaching puts the teacher at the centre of the teaching and learning process and provides very little space for pupils' contribution in the teaching and learning process (Groth, 2013). This sequence of teaching has the tendency to inform what teachers find important in the teaching of mathematics and science and hence their views about the teaching of same. There is the need to look at a better alternative sequence of presentation of lessons that will contribute in helping teachers develop pupil-centred views on teaching.

Although this study involved only 157 primary and junior high school teachers, the results may provide insight into what the views of many primary and junior high school teachers are and how their views may be affecting their practices. This calls for replication of the study on a wider scale to get a better picture of the situation.

\title{
References
}

Abenyega, J., \& Davis, E. K. (2015). Exploring the intersection of English as an instructional language and inclusive pedagogy in primary mathematics classroom in Ghana. International Journal of Whole Schooling. 11(2), $45-64$.

Ampiah, J. G., Davis, E. K., \& Kuupole, A. (2013). Exploring mentees' expectations and experiences of mentorship: The case of Colleges of Education in Ghana. Ghana Journal of Education: Issues and Practice, 4(1), 86 - 107.

Borg, M. (2001). Key concepts in ELT teachers' beliefs. ELT Journal, 55 (2), 186-188.

Brady, L. (1985). Models and Methods of Teaching. Printice-Hall of Australia Pty Ltd., Sidney.

Calderhead, J. (1996). Teachers: Beliefs and Knowledge. In D. Berliner \& R. Calfee (Eds.), Handbook of educational psychology, (pp. 708-725). New York: Macmillan.

Davis, E. K. (2018). Mathematics classroom discourse in typical Ghanaian public school: How does it look like? The Oguaa Educator, 12(1), 1-27.

Davis, H., \& Andrzejewski, C. (2009). Teacher beliefs. Retrieved from http://www.education.com/reference/article/teacher-beliefs/\#D.

Dembo, M. H. (1977). Teaching for learning: Applying educational psychology in the classroom. Santa Monica, CA: Goodyear. 
Ernest, P. (1988). The Impact of Beliefs on the Teaching of Mathematics. Paper was presented as at the 6th International Congress of Mathematical Education, Budapest, August.

Ernest, P. 1989. The impact of beliefs on the teaching of mathematics. In P. Ernest (eds.) (Mathematics teaching, pp. 249-254). The state of art. New York: The Falmer Press.

Fang, Z. (1996). A review of research on teacher beliefs and practices. Educational Research, 38(1), 47-64.

Galvis, H. A. (2012). Understanding beliefs, teachers' beliefs and their impact on the use of computer cechnology. PROFILE, 14 (2), 95-112.

Groth R. E. (2013). Teaching mathematics in grades 6-12. Los Angeles, SAGE.

Institute of Education. (2014). Three-year diploma in basic education five-semester programme revised syllabus. Cape Coast: University of Cape Coast.

Kagan, D. (1992). Implications of research on teacher belief. Educational Psychologist, 27(1), 6590.

Mansour, N. (2009). Science teachers' beliefs and practices: Issues, implications and research agenda. International Journal of Environmental and Science Education, 4(1), 25-48

Meighan, R., \& Meighan, J. (1990). Alternative roles for learners with particular reference to learners as democratic explorers in teacher education courses. The School Field, 1(1), 6177.

MOE. (2012a). National Syllabus for Integrated Science (Junior High School). Accra: Curriculum Research and Development Division

MOE. (2012b). National Syllabus for Mathematics (Junior High School 1-3). Accra: Curriculum Research and Development Division

Mullis, I. V. S, Martin, M. O., Foy, P., \& Arora, A. (2012). TIMSS 2011 international results in mathematics. Chestnut Hill, MA: TIMSS \& PIRLS International Study Centre.

Nespor, J. (1987). The role of beliefs in the practice of teaching. Journal of Curriculum Studies, 19(4), 317-328.

Perkilla, P. (2003). Primary school teachers' mathematics belief and teaching practice. https://www.researchgate.net/publication/252071815_PRIMARY_SCHOOL_TEACHERS\%27_MATHEMATICS_BELIEFS_AND_TEAC̄HING_PRĀCTICES

Williams, M., \& Burden, R. L. (1997). Psychology for language teachers: Social constructivist approach. Cambridge: Cambridge University Press. 
Primary and junior high school mathematics and science teachers' views on teaching in the Cape Coast Metropolis of Ghana

E. K. Davis, C. Beccles, \& E. C. Intsiful

\section{APPENDIX A QUESTIONNAIRE FOR TEACHERS}

This questionnaire elicits information about mathematics and science teachers' views on teaching. Your candid response to the items would be appreciated. The information you provide would be used for research purpose only. Your contribution to this study will go a long way to improve the delivery of teacher education in the country.

\section{PART 1}

This section elicits your biographical information. For items 1-5 please tick the appropriate box.

1. Indicate the level at which you teach.

$$
\begin{aligned}
& \text { Primary School } \\
& \text { Junior High School }
\end{aligned}
$$

2. In which circuit is your school?

Cape Coast

OLA

Aboom

Bakano

Abura/Pedu

Efutu

3. Sex

Male

Female

4. Years of teaching experience

Less than 5 years

5-10 years

11-15 years

16-20 years

20-25 years

Above 25years

5. Are trained as a teacher?

$\begin{array}{ll}\text { Yes } & \square \\ \text { No } & \square\end{array}$


African Journal of Educational Studies in Mathematics and Sciences Vol 15, No. 2. 2019

\section{PART 2}

This section elicits your views about teaching. For items $6-15$, please write your response in the space provided under each item.

6. In your view, what is learning?

7. What do you think is the main function of a teacher in the teaching and learning process?

8. In your view, who decides what is right or wrong in the lesson and why?

9. In your view, who decides what should be learned, how it should be learned and when?

10. In a typical Ghanaian classroom there is always a teacher and students. Describe how you think interaction in the classroom should be.

11. How do you determine whether the student have understood what they are taught?

12. How do you determine whether the students have mastered the programme they study?

13. In your view, who determines whether or not the lesson achieved its objectives and why?

14. In many Ghanaian schools, it is common to find classroom organisation where individual seat work or group work is carried out. In your view, which of them should be emphasised and why?

15. In your view, who should control the teaching and learning process in the classroom and why? 
Primary and junior high school mathematics and science teachers' views on teaching in the Cape Coast Metropolis of Ghana

E. K. Davis, C. Beccles, \& E. C. Intsiful

\section{Appendix B: Sample of Responses on Item 6 (i.e. In Your View, What Is Learning?")}

\begin{tabular}{|c|c|c|}
\hline Continuum & Response & $\mathbf{N}(\%)$ \\
\hline \multirow{36}{*}{$\begin{array}{l}\text { Teacher- } \\
\text { Centered }\end{array}$} & Is the process of acquiring knowledge or an act in which something is learned (T 12) & \multirow{36}{*}{$\begin{array}{c}110 \\
(70.1 \%)\end{array}$} \\
\hline & Acquisition of knowledge through the use of domains (T54) & \\
\hline & $\begin{array}{l}\text { Learning is the process of setting knowledge of something or the process of gaining } \\
\text { ability to do something or process of acquiring knowledge (T 15) }\end{array}$ & \\
\hline & Is acquisition of knowledge (79) & \\
\hline & It is the process of acquiring knowledge through any form of education (T 16) & \\
\hline & Is the process of acquiring knowledge ( $\mathrm{T} 26$ ) & \\
\hline & The process of acquiring knowledge in order to make changes (T 33) & \\
\hline & Is a process of obtaining knowledge of facts or understanding of ideas (T 40) & \\
\hline & Learning is the process of acquiring skills or knowledge (T 7) & \\
\hline & $\begin{array}{l}\text { It is the process of acquiring knowledge from a knowledgeable person or teacher ( } \mathrm{T} \\
80 \text { ) }\end{array}$ & \\
\hline & Learning is the process of acquiring knowledge (T 49) & \\
\hline & It is the process of gaining knowledge about something ( $\mathrm{T}$ 141) & \\
\hline & Learning is the process of acquiring knowledge ( $\mathrm{T} 142$ ) & \\
\hline & $\begin{array}{l}\text { Learning is a process of imparting knowledge in any form into individuals under an } \\
\text { organized setting ( } \mathrm{T} 156)\end{array}$ & \\
\hline & Learning is a process of acquiring knowledge formally or informally (T 163) & \\
\hline & Learning is the acquisition of knowledge (T 161) & \\
\hline & Learning is the acquisition knowledge and development ( $\mathrm{T}$ 154) & \\
\hline & Learning is the acquisition of knowledge and intellectual development (T 100) & \\
\hline & Learning is acquisition of knowledge (T 98) & \\
\hline & $\begin{array}{l}\text { Learning is acquisition of knowledge or to get knowledge of some-thing or the ability } \\
\text { to do something (T 65) }\end{array}$ & \\
\hline & Is the acquisition of knowledge through study experience or being taught ( $\mathrm{T} 66)$ & \\
\hline & Learning is acquiring of knowledge (T 67) & \\
\hline & Learning is to get knowledge of something or the ability to do something (T 68) & \\
\hline & $\begin{array}{l}\text { Learning is acquisition of knowledge to course (sic) a change in the behaviour of an } \\
\text { individual (T 57) }\end{array}$ & \\
\hline & It is the knowledge gained by an individual by reading or studying ( $\mathrm{T} 60$ ) & \\
\hline & Learning is acquisition of knowledge ( $\mathrm{T} 42$ ) & \\
\hline & Learning is acquisition of knowledge ( $\mathrm{T} 43$ ) & \\
\hline & Learning is causing a permanent change of behavior in a person ( $\mathrm{T} 44)$ & \\
\hline & Learning is the act of acquiring new knowledge ( $\mathrm{T} 47$ ) & \\
\hline & Learning is the act of acquiring knowledge (T 50) & \\
\hline & Learning is gaining knowledge about something ( $\mathrm{T} 17$ ) & \\
\hline & Acquisition of knowledge (T 20) & \\
\hline & Acquisition of knowledge (T 29) & \\
\hline & It is the act of getting knowledge ( $\mathrm{T} 11$ ) & \\
\hline & learning is acquiring knowledge (T 24) & \\
\hline & Learning is to gain knowledge from something ( $\mathrm{T} 13$ ) & \\
\hline
\end{tabular}




\begin{tabular}{|c|}
\hline Is the acquisition of knowledge through study experience or being taught (T 69) \\
\hline $\begin{array}{l}\text { Learning is the knowledge acquired through training, experience or apprenticeship ( } \mathrm{T} \\
\text { 70) }\end{array}$ \\
\hline Learning is the acquiring of knowledge (T 71) \\
\hline Learning is the art of acquiring knowledge ( $\mathrm{T} 72$ ) \\
\hline $\begin{array}{l}\text { Learning is a total acquisition of knowledge from all aspect of one's or individual life } \\
\text { ( } \mathrm{T} 75)\end{array}$ \\
\hline $\begin{array}{l}\text { Learning is a total acquisition of knowledge from all aspect of one's of individual life } \\
\text { (T 76) }\end{array}$ \\
\hline $\begin{array}{l}\text { Learning is a total acquisition of knowledge from all aspect of one's or individual life } \\
\text { (T 77) }\end{array}$ \\
\hline Learning is the acquisition of knowledge and intellectual development (T 78) \\
\hline $\begin{array}{l}\text { Learning is the act of acquiring new or changing or adding up to existing knowledge, } \\
\text { skills, behaviour, etc. ( } \mathrm{T} 18 \text { ) }\end{array}$ \\
\hline $\begin{array}{l}\text { It is the acquisition of knowledge, facts information through observation, } \\
\text { experimentation reading and demonstration }(\mathrm{T} 84)\end{array}$ \\
\hline $\begin{array}{l}\text { Learning is the act of acquiring knowledge through reading, researching and asking } \\
\text { from experts opinion ( } \mathrm{T} 86 \text { ) }\end{array}$ \\
\hline Is the process of acquiring knowledge ( $\mathrm{T} 110$ ) \\
\hline Is a process of acquiring knowledge ( $\mathrm{T} 112$ ) \\
\hline It is a way of acquiring knowledge through observation, etc. (T 113) \\
\hline Learning is the acquisition of knowledge ( $\mathrm{T} 115$ ) \\
\hline Acquiring knowledge through various activities (T 116) \\
\hline Learning is acquisition of knowledge development ( $\mathrm{T}$ 117) \\
\hline Learning is the acquisition of knowledge and intellectual development ( $\mathrm{T} 118$ ) \\
\hline $\begin{array}{l}\text { When there is acquisition of knowledge or skills that is where learning takes place (T } \\
\text { 121) }\end{array}$ \\
\hline Learning is the acquisition of knowledge and intellectual ( $\mathrm{T}$ 122) \\
\hline Learning is acquisition of knowledge intellectual development (T 123) \\
\hline Learning is acquiring knowledge ( $\mathrm{T} 124)$ \\
\hline $\begin{array}{l}\text { It is the acquisition of knowledge directly or indirectly which has an impact on the } \\
\text { learner ( } \mathrm{T} 51 \text { ) }\end{array}$ \\
\hline Learning is acquisition of knowledge; intellectual development (T 53) \\
\hline $\begin{array}{l}\text { Learning is the act of acquiring new or modifying and reinforcing existing knowledge } \\
\text { and behaviours which may lead to a potential change in information or behaviour } \\
\text { relative to the type of experience ( } \mathrm{T} 125)\end{array}$ \\
\hline $\begin{array}{l}\text { It is the acquisition of knowledge. It is the process of acquiring knowledge from } \\
\text { someone ( } \mathrm{T} 128)\end{array}$ \\
\hline Is the method of acquiring knowledge ( $\mathrm{T}$ 129) \\
\hline Is the method of acquiring knowledge through development ( $\mathrm{T} 158$ ) \\
\hline Learning is the act of acquiring knowledge through studying ( $\mathrm{T}$ 138) \\
\hline Acquiring knowledge for a change (T 61) \\
\hline Acquiring of knowledge through interaction (T 5) \\
\hline Change in behaviour ( $\mathrm{T} 4)$ \\
\hline Imparting knowledge (T 6) \\
\hline $\begin{array}{l}\text { Learning occurs when pupils are able to give correct feedback/responses to what has } \\
\text { been taught }(\mathrm{T} 8)\end{array}$ \\
\hline
\end{tabular}


Primary and junior high school mathematics and science teachers' views on teaching in the Cape Coast Metropolis of Ghana

E. K. Davis, C. Beccles, \& E. C. Intsiful

\begin{tabular}{|c|}
\hline Learning is accumulated information gained from a study (T 9) \\
\hline It is a change in behaviour ( $\mathrm{T} 25)$ \\
\hline $\begin{array}{l}\text { Learning is when a pupil has understood the topic taught and the pupil is able to re- } \\
\text { produce what has been taught for the day (T 35) }\end{array}$ \\
\hline $\begin{array}{l}\text { Learning is a relatively change in behaviour which comes about as a result of } \\
\text { reinforced practice ( } \mathrm{T} 73 \text { ) }\end{array}$ \\
\hline It is a relative change in behaviour as a result of constant practice $(\mathrm{T} 87)$ \\
\hline Is an outwards change in behaviour of a person ( $\mathrm{T} 88)$ \\
\hline $\begin{array}{l}\text { Learning is a process of assimilating something you already don't know and therefore } \\
\text { helps you to have a change in behaviour ( } \mathrm{T} 89)\end{array}$ \\
\hline learning is an act in which something is learned (T 101) \\
\hline Learning is any activity or process which aims at getting knowledge (T 107) \\
\hline Is the ability of children to acquire knowledge ( $\mathrm{T} 109)$ \\
\hline Learning is the acquisition of knowledge being impacted ( $\mathrm{T} 135)$ \\
\hline $\begin{array}{l}\text { Learning is a relatively change in behaviour that occurs as a result of reinforced } \\
\text { practice ( } \mathrm{T} 137)\end{array}$ \\
\hline Acquire new ideas (T 144) \\
\hline Learning is the process of acquiring knowledge through reading ( $\mathrm{T}$ 147) \\
\hline Learning is a means of acquiring knowledge either by formal or informal ( $\mathrm{T} 152$ ) \\
\hline A change in behaviour ( $\mathrm{T} 155)$ \\
\hline It is a means of acquiring knowledge ( $\mathrm{T} 134)$ \\
\hline Learning is a process of acquiring knowledge and skills (T 99) \\
\hline Learning is the acquisition of acquiring knowledge and skills ( $\mathrm{T} 120$ ) \\
\hline Learning is acquisition of knowledge and skills ( $\mathrm{T} 2$ ) \\
\hline Is the process of acquiring knowledge, skill, ideas etc. (T 97) \\
\hline Is the process of acquiring knowledge and skill ( $\mathrm{T} 21$ ) \\
\hline Is the process of acquiring knowledge and skills ( $\mathrm{T} 22$ ) \\
\hline Is the process of obtaining knowledge and skills ( $\mathrm{T} 23$ ) \\
\hline The process of gaining knowledge and skills ( $\mathrm{T} 28$ ) \\
\hline $\begin{array}{l}\text { Learning is a process of acquiring knowledge and skill through an instructor to effect } \\
\text { change in behaviour of the learner ( } \mathrm{T} 95)\end{array}$ \\
\hline Learning is the acquiring knowledge and skills ( $\mathrm{T}$ 102) \\
\hline Learning is the acquisition of knowledge and skills ( $\mathrm{T}$ 55) \\
\hline Acquisition of knowledge and skills into an individual (T 93 ) \\
\hline Acquiring knowledge and developing skills ( $\mathrm{T}$ 34) \\
\hline Learning is the art of acquiring knowledge and skills in doing an activity ( $\mathrm{T} 145$ ) \\
\hline Learning is the method of acquiring skills and knowledge ( $\mathrm{T} 143$ ) \\
\hline Learning takes place when knowledge is acquired and skills are developed ( $\mathrm{T}$ 31) \\
\hline $\begin{array}{l}\text { It is the process of imparting learning knowledge and relevant skills unto pupils ( } \mathrm{T} \\
153 \text { ) }\end{array}$ \\
\hline Learning is the acquisition of knowledge, skills and Intellectual development (T 85) \\
\hline The acquisition of knowledge and skills that result in a behavioural change ( $\mathrm{T}$ 81) \\
\hline It the acquisition knowledge and skills that result in a change of behaviour (T 83) \\
\hline Is acquisition of knowledge, change of behaviour and acquiring skills (T 41) \\
\hline
\end{tabular}




\begin{tabular}{|c|c|c|}
\hline & $\begin{array}{l}\text { learning is the act of acquiring knowledge to enable you to apply it in the field of } \\
\text { study (T 62) }\end{array}$ & \\
\hline \multirow[t]{30}{*}{$\begin{array}{l}\text { Student- } \\
\text { Centered }\end{array}$} & $\begin{array}{l}\text { Learning is a continuous process where people seek to know more about their } \\
\text { environment }(\mathrm{T} 1)\end{array}$ & \multirow[t]{30}{*}{$\begin{array}{c}44 \\
(28.0 \%)\end{array}$} \\
\hline & Is the process of acquiring knowledge and skills for total development ( $\mathrm{T} 3$ ) & \\
\hline & Is the acquisition of Knowledge and skills to better ones life ( $\mathrm{T} 27$ ) & \\
\hline & $\begin{array}{l}\text { Is the act of acquiring new or modifying and reinforcing existing knowledge, } \\
\text { behaviours, skills and values ( } \mathrm{T} 32 \text { ) }\end{array}$ & \\
\hline & $\begin{array}{l}\text { It is the process of acquiring knowledge, skills, attitudes etc in the individual or the } \\
\text { learner (T 38) }\end{array}$ & \\
\hline & $\begin{array}{l}\text { Learning is the act of acquiring new or modifying and reinforcing existing knowledge } \\
\text { behaviours, skills, values or preferences which may lead to potential change in } \\
\text { synthesizing information ( } \mathrm{T} 46 \text { ) }\end{array}$ & \\
\hline & $\begin{array}{l}\text { Learning is the process of acquiring knowledge, skills and attitudes for societal and } \\
\text { personal enhancement ( } \mathrm{T} \text { 52) }\end{array}$ & \\
\hline & $\begin{array}{l}\text { Is the acquiring knowledge of which one uses the acquired knowledge to solve } \\
\text { problems in the society ( } \mathrm{T} 74 \text { ) }\end{array}$ & \\
\hline & Acquiring knowledge or skill to solve a problem (T 108) & \\
\hline & Is a permanent change in behaviour. It is also an experience gained. (T 119) & \\
\hline & It is the development of experience through knowledge acquisition (T 48) & \\
\hline & Learning is a change in behaviour as a result of an experience an activity etc. ( $\mathrm{T} 127$ ) & \\
\hline & $\begin{array}{l}\text { It is the activity or process of gaining knowledge or skill by studying, practicing or } \\
\text { experiencing something ( } \mathrm{T} 14)\end{array}$ & \\
\hline & Learning is creating the environment for the children to learn and applying it ( $\mathrm{T}$ 132) & \\
\hline & Learning is acquisition of knowledge and its application in life ( $\mathrm{T} 133$ ) & \\
\hline & $\begin{array}{l}\text { A process of acquiring knowledge, skills and values through experience, } \\
\text { demonstration and observations ( } \mathrm{T} 136)\end{array}$ & \\
\hline & $\begin{array}{l}\text { Learning is the activity of obtaining knowledge. It promote transfer of knowledge ( } \mathrm{T} \\
\text { 139) }\end{array}$ & \\
\hline & The process of acquiring knowledge and applying it in our daily lives ( $\mathrm{T} 151$ ) & \\
\hline & $\begin{array}{l}\text { Learning is acquisition of knowledge, intellectual development, social interaction etc. } \\
\text { (T 157) }\end{array}$ & \\
\hline & Learning is acquisition of experience affective development (T 160) & \\
\hline & Learning is the transfer of knowledge and intellectual development (T 114) & \\
\hline & It is a change in behaviour due to experience ( $\mathrm{T} 90)$ & \\
\hline & It is a relative change in behaviour as a result of practice or experience ( $\mathrm{T} 91$ ) & \\
\hline & Learning is a relative change in behaviour as a result of experience ( $\mathrm{T}$ 92) & \\
\hline & It is a relative change in behaviour as a result of practice or experience ( $\mathrm{T} 94$ ) & \\
\hline & $\begin{array}{l}\text { To gain or acquire knowledge of or skill in something by study, experience or being } \\
\text { taught ( } \mathrm{T} 130)\end{array}$ & \\
\hline & $\begin{array}{l}\text { It refers to the systematic change in behaviour or behavioral disposition that occurs as } \\
\text { a consequence of experience ( } \mathrm{T} 131)\end{array}$ & \\
\hline & It involves the acquisition knowledge and skills from an experience (activity) (T 149) & \\
\hline & $\begin{array}{l}\text { It is the acquisition of knowledge and skills through interaction and manipulating of } \\
\text { materials (T 148) }\end{array}$ & \\
\hline & $\begin{array}{l}\text { Learning is the process of acquiring knowledge and skills through teaching and other } \\
\text { experiences ( } \mathrm{T} \text { 126) }\end{array}$ & \\
\hline
\end{tabular}


Primary and junior high school mathematics and science teachers' views on teaching in the Cape Coast Metropolis of Ghana

E. K. Davis, C. Beccles, \& E. C. Intsiful

\begin{tabular}{|c|c|c|}
\hline & $\begin{array}{l}\text { The process of acquiring knowledge and skills through explanation, demonstration, } \\
\text { participation and situation ( } 140)\end{array}$ & \\
\hline & $\begin{array}{l}\text { is the acquisition of knowledge and skills through study, experience or being taught } \\
\text { (T 63) }\end{array}$ & \\
\hline & $\begin{array}{l}\text { Learning is the acquisition of knowledge and skills through study, experience or being } \\
\text { taught (T 64) }\end{array}$ & \\
\hline & It is the process of acquiring knowledge or skill(s) through experience (T 37) SC & \\
\hline & $\begin{array}{l}\text { Learning is the acquisition of knowledge or skill through study, experience, or being } \\
\text { taught (T 58) }\end{array}$ & \\
\hline & $\begin{array}{l}\text { Learning is the acquisition of knowledge or skills through study, experience or being } \\
\text { taught (T 36) }\end{array}$ & \\
\hline & $\begin{array}{l}\text { Gaining knowledge or skill through teaching, studying, practicing and experiencing } \\
\text { (T 45) }\end{array}$ & \\
\hline & $\begin{array}{l}\text { Learning is the process of gaining knowledge or skill by studying practicing being } \\
\text { taught or through experiences ( } \mathrm{T} 30)\end{array}$ & \\
\hline & Is the acquisition of knowledge or skills through experience being taught ( $\mathrm{T}$ 19) & \\
\hline & The acquisition of knowledge, skills through study, experience or being taught ( $\mathrm{T} 10)$ & \\
\hline & $\begin{array}{l}\text { The activity or process of gaining knowledge or skill by studying, practicing, being } \\
\text { taught ( } \mathrm{T} 146)\end{array}$ & \\
\hline & $\begin{array}{l}\text { The process by which a person acquires knowledge and skills through formal and } \\
\text { informal means to better ones life ( } \mathrm{T} 150)\end{array}$ & \\
\hline & $\begin{array}{l}\text { Learning is the acquisition of knowledge or experience for effective development of } \\
\text { skills (T56) }\end{array}$ & \\
\hline \multirow{3}{*}{$\begin{array}{l}\text { Unclear } \\
\text { response }\end{array}$} & Learning is a change in human (an individual) that results from experience ( $\mathrm{T} 39$ ) & \multirow[t]{3}{*}{$3(1.9 \%)$} \\
\hline & learning is detection and correction at error ( $\mathrm{T} 82)$ & \\
\hline & Instruction and acceptance (T 96) & \\
\hline
\end{tabular}

